\title{
Features of Rural Settlements: Gjirokastra Region Case
}

\author{
Albina Sinani \\ Associate Professor, "Eqrem Çabej" University, Gjirokastër, Albania, Department of Geography, \\ Faculty of Education and Social Sciences, Gjirokastër, Albania \\ Email: sinalbina@yahoo.com
}

\section{Doi:10.5901/ajis.2016.v5n3s1p269}

\section{Abstract}

Like other scholars of different disciplines, geographers have established their particular feature, through numerous studies. Proper studies, such as studies of the settlements and the degree of use of rural territories, are carried out even in the field of rural geography. The vast majority of settlements as well as most of human potential in the territory of Albania (about 58\%) are located in the rural area. Geographical contributions to the study of rural settlements consist in high levels of information also in their dynamics related to time and space, necessary for decision-making institutions in the service of sustainable rural development. Support specialists in various fields, the role of geography are a priority in the study of rural areas settlements, on the basis of natural knowledge, socio-economic and diverse research methods. During the historical periods, depending on natural, political, socio-economic factors, the demographic and administrative organization of urban and rural areas in Albania have established their physiognomy and authenticity. The number, scope and functions of rural areas settlements have been the subject of study carried out by many authors who have analyzed not only nationally, but also regionally and locally. $A$ particular case is the district of Gjirokastra, where the rural migration has brought about many negative effects. Administrative divisions have a direct impact on the number, size and rational distribution of settlements. During the previous regime, their network was transformed, not only in spatial terms, but also from the functional point of view and typology-wise. After 1989, political, economic and legal changes brought about the need to alter the old forms of governance and the performance of the administrative-territorial reform had a multilateral impact on the network of rural settlements.

Keywords: rural settlements, rural development, material culture, terraces, rural dwellings

\section{Introduction}

Documents with a great deal of information about rural settlements and their economy have been made available recently.

We should say that Ottoman cadastres are of great value regarding their extensive and detailed information because in them it is clearly documented the true nature, size, main economic resources, relations with civic centers, economic power, role of agriculture, crops, in the Albanian medieval village ${ }^{1}$.

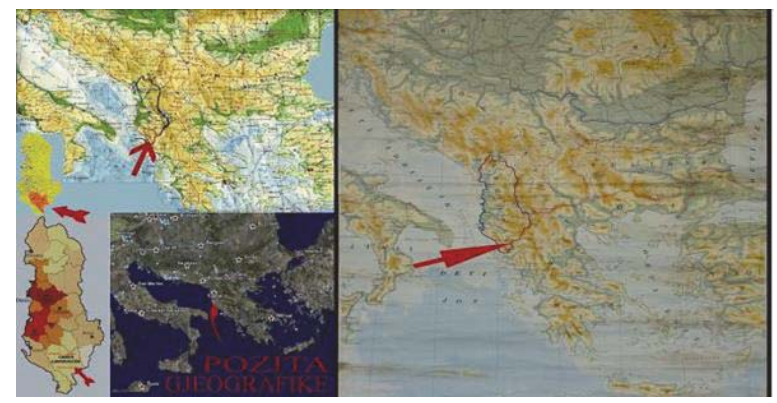

Fig. 1. Geographical position of Gjirokastra region

1 Shkurti. S. Albanian Ethnography Nr. 17. Rural settlements and agricultural economy in medieval Albania. Page 4-35. Tiranë 1997. 


\section{Theory and Methodology}

Typology is varied and reflects the special features of natural, historical, psychological, ethnographic and economic factors.

According to the size criterion we have:

a. small village, up to 500 inhabitants, 69 ones that occupy $72 \%$ of the total area.

b. average village, $500-1000$ inhabitants, 21 ones that occupy $22 \%$ of the total area.

c. large village, over 1000 inhabitants, 6 ones or $6 \%$ of the total area.

According to the method of construction and location there are:

a. compact.

b. with regular structure

c. listed structure

d. spread, with stray houses, but with arrable land

e. linear, in terms of typology of road infrastructure, ease of communication and transport

According to the schematic presentation of the setting there are:

a. linear expansion, as opposed to the road network, river, water

b. circular stretch, around a central square

Just by looking at a given village we can say that their shape is an adaptation to the natural and social conditions.

\section{Results and Discussion}

In the work "The Albanian population" is analyzed the network of residential centers. During the years of socialist construction in the country, as a result of the economic factors the network of rural residential areas expanded in three ways:

1. Through the process the establishment of socialist relations in agriculture, land reclamations, river restoration, the opening of new lands.

2. Through the development of a series of sites located in lowland areas of the country as a new village center

3. Through the establishment of residential centers after earthquakes

Each geographical area, under the influence of a number of social, economic, geographical and historical factors has established its own network of residential centers, with their particular physiognomy, size, layout and construction features.

Of special interest is the analysis of the distribution of settlements according to their elevation, through which it is seen the degree of uniformity of the population within the territory of our country (hilly in percentage). By analyzing the overall development of socio-economic, geographical, urban dynamics, landscape features, administrative organization, we notice a varied typology of settlements.

The size of the settlements and their economy were closely similar to each other. The development of the agricultural economy (three categories: cultivated lands, vineyards and gardens) depend to a large extent on the amount of people able to work, consequently on the size of the dwelling.

Fields account for the majority of land under culture; they were an important indicator which established the character of a settlement. Lands are used for two purposes which show that agriculture and animal husbandry have been the two main economic activities, tied and intertwined with each other. The Ottoman records of the XV-century provide a clear panorama concerning the peasant settlements, there we can find a thorough information about the Albanian Vilayets, carried out in 1431-1432, with an overall average of Albanian Sanjak, consisting of 20.8 houses for each township.

The most populated parts were the hilly areas of South Albania and to a smaller degree the western coastal areas of Albania and hilly villages in their vicinity. Rural areas are the earliest settlements, which have existed throughout the history of the development of Albanian society.

Various authors have identified various features of rural settlements ${ }^{2}$. In ancient times as a result of the concentration of population on mountaintops, animal husbandry was the main economy activity which enabled the survival of the population.

${ }^{2}$ Axhemi. S. Geography of the population and settlements. Page 190-211. ALSA. Tiranë 2007. 
An important step in the development of rural areas was the gradual shifting to permanent housing as opposed to the temporary settlements. Agriculture and animal husbandry made it possible to create conditions suitable for living. Construction of various settlements using stone spread rapidly within a short period of time.

Stone was present everywhere, easy to find and therefore their spread was massive and quite fast.

Continuous improvement of these settlements was evident in the architectural aspect of the bulidings, in the developmental stages and social organization, in the material culture and traditions associated with the different forms of architecture and functions of these settlements.

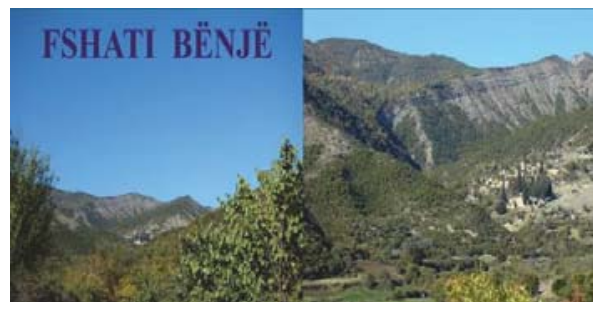

Fig. 2. Village of Bënjë (Përmeti district)

Apart from the aspects that were related to residential buildings, settlements became more diverse in terms of their characteristics regarding their texture.

Various authors have proposed different criteria and classifications closely related to geographic and topographic aspects (mountainous villages, hills and plains) and the territorial-administrative as well as depending on the economic activity that takes place in it. In the work of Mark Tirta ${ }^{3}$ concrete evidence is provided about the internal organization of traditional villages. Evidence pointing to a practice of settlement tradition is much earlier than the fifteenth century. Archeological excavations show signs of villages dating from this century, but also fortifications which show a significant socio-economic development. We have houses built in stones (located on slopes or on rocks, which resemble small fortresses) as farming was the main form of economic activity among the Mediterranean people. In many villages preceding the Ottoman period viticulture, and farming were developed. The inner movements from one place to another, from mountainous to valley areas, brought isolated rural areas closer to urban centers economically, politically, and socially.

Corn growing at this time assumed great proportions something wich goes to show that the population is moving from the mountains to the fields.

Through numerous testimonies we see that the population in these settlements for the most part derives from the mountainous areas during the second half of the XIX century and in the first half of XX century.

Bringing new land under cultivation, led to the development of new realities of socio-economic and ethno-cultural life, which was a powerful factor in the interregional communication, as well as market expansion through the utilization of economic resources, which in turn led to an increase in the rate of production and a better standard of living which was previously something unusual for the population. The withdrawal of the population in the mountains happened because of special reasons of a political nature (the great cruelty of the invaders). Demands for new economic resources made in the late nineteenth and early twentieth century, resulted in the shifting of population from the mountains into the fields, something which paved the way for social transformations and developments. Different villages grew at the junctions of main roads linking different regions of our country. People tended to group themselves near the handicrafting centers, in this way the lot of them who could not cultivate land could make a living in the city. From ancient authors we learn that ".. all Epirus and Illyria are densely populated ${ }^{4 " .}$

This fact regarding the density of population in antiquity is reinforced in Tit Livi's work "The establishment of the city $^{5 "}$. Later the number of settlements grew further, but this growth and the following development, were set off as a result of numerous wars and destructions brought about by various invaders. According to Evlia Çelebiu, who visited

3 Tirta. M. Albanian Ethnography 18. Migrations of the Albanians. Page 32-71. 169-171. Science. Tiranë 1999.

${ }^{4}$ Straboni. Geography. Moscow 1964. Page 295.

5 The Illyrians and Illyria by the ancient authors. Tiranë 1965. Page 133. 
Përmet, during the second half of XVII century, Përmet had at that time 150 housing units 6 .

Further information concerning the demographic data about the settlement areas is provided by the works of French scholar, Pouqueville, at the beginning of XIX century. Accurate data regarding the number of shops, houses, bridges, religious institutions, farms can be found in Sami Frashëri's work "Kamus-ul Alam p. 1500-1501".

During the years the traditions and the countryside dwellings underwent some changes depending on the economic and social position of the people living in them. The interior of the houses is distinguished by wonderful decorations and inscriptions related to their folk tradition.

A great deal of information is offered also in "Albania in 1927" where we can find accurate information concerning the socio-economic and demographic situation of Albania before World War II. The book serves as a reference for many geographers who have studied rural areas. This work proves the vital importance statistics have played throughout the centuries regarding the development of rural areas.

Under the influence of economic, political, social and administrative factors, rural settlements once again underwent changes regarding their geographical position, they extended or shrank respectively. In the 1431-1432 census Permet province had 121 villages with 3525 houses (21 families/village), and Këlcyra had 41 villages with 1029 houses (25 families/village). The province of Permet included 148 villages in 1840, 1872 had 118 villages, 1923, 105 villages and 104 villages in 1938. In these villages, handicraft items like baskets, saddles, etc were the main forms of economic activity. Starting from 1995, Permet district, as part of Gjirokastra prefecture, consists of 93 villages divided into six municipalities: Center (28 villages), Suke (13), Ballaban (14) Kelcyre (21), Çarçovë ( 9) Frashër (8) ${ }^{8}$.

The establishment of the Ottoman military-feudal regime was associated with the destruction of 15 villages in the provinces of Shqerri and Dangëlli and ruins of some of the abovementioned villages can be seen today. Other elements which prove of the existence of such villages are graves or toponyms like: Lëkurësi, Stojani, Dardhësi, Taraniku, Katundishta, Vinjahu, Teperi etc.. At the end of the XIX century, Gjirokaster region underwent significant socio-economic changes.

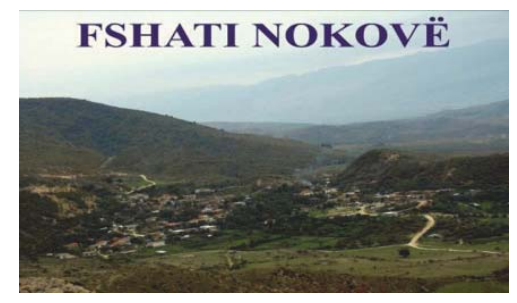

Fig. 3. Nokove village (Gjirokastra district)

From the economic point of view the area was a backward agrarian entity with a distinct rural and agricultural character. The majority of the population Is employed in agriculture and animal husbandry. In the early XIX century Permet experienced a fast-growing period with a population reaching up to 155 villages. An important center was Frasher, the birthplace of the Frasheri brothers, distinguished personalites of Albanian renaissance. Frashër, which is a small mountain town, is named after them. Geographer A.Th. Psalidha from Ioannina, which is a city in in Greece with 116 villages, called Frashër "second city" after the Permet. F. Pouqueville, who was among other things, Napoleon Bonaparte's general consul at the court of Ali Pasha of Ioannina, called Frashër the largest village out of 48 villages included in the then province of Dangëllia. The locals there were involved in agriculture, handicrafts and trade. As regards the societal structure Frasher resembled Albania in miniature. From the religion point of view, here we should mention the foundation of "Tahir Skenderasi" Tekke of Frashër in 1815, whose historical values are recorded in history books. In this tekke in 1880, Abdyl Frashëri called a special gathering of representatives of the Albanian provinces (Vilayet of Monastir and loannina), and there he addressed two important issues: the protection of territorial integrity and the formation of an independent Albanian vilayet.

These settlements besides being centers in which handicraft items were produced, served also as centers in which

\footnotetext{
${ }^{6}$ Adhami. S. Overview of popular culture of the region of Përmet . page 22-126. GERVIS. Tiranë 2001.

7 Selenica. T. Albania in 1927. Page. TIRANA. Tiranë 1928.

${ }^{8}$ Lole. Dh. Përmet and its areas until 1912. LUARASI. Page 14-96. Tiranë 2000.
} 
agricultural raw materials were processed, paper and textiles were also produced, wool processing like carding, weaving, dyeing also took place there.

Present in these settlements were also leather processing and the production of copper and bronze vessels which were sold weekly in the markets of Përmet, Kelcyre and Frashër.

So handicraft items constitute the main economic activity in these places.

This economic system centering on handicrafted items helped establish the necessary economic ties and giving rise to a domestic market that would strengthen the urban-rural relations. Even the author of the book "Çamëria", talks about the general geographical features of 279 villages, settlements of ethnic Albanians whose population was forced to leave their ancestral land in 1944-1945.

These settlements were located in coastal alluvial areas, terraces of river valleys, mountainous areas on the western slopes in soft undulating hills. The most common type is the small rural centers with 50-100 home. After the second half of the XX century we witness a revival of the architectural typology of old traditional houses with two stories.

Socio-economic conditions, the topography of the terrain, construction materials and popular masters have determined apartment's architectural composition. This area is dominated by tower-like houses of great architectural value. The main economic activity was agriculture. At present there Is some evidence, in the form of destroyed homes, mosques, towers, which have been able to remain to this day due to the fact of being isolated in hills or hidden underground therefore not being affected by erosion on the outskirts of the new settlements, which point to a once populous region. These buildings represent important historical monuments in this geographical serving as examples of Venetian and Ottoman influence in this part of Eastern Europe. Especially in the Vjosa valley and its Drino tributary which served as important trade arteries and strategic military points, in the XV century, in the context of the Turkish invasion, the population of many rural settlements was forcibly displaced or left to escape persecution. Destroyed villages in the provinces of Shqeri and Dangëlli, are a proof of villages being destroyed in the middle Ages in the wake of the Turkish invasion. Such settlements by now in ruins are: Lëkurësi, Drenova, Vinjahu Stojani, Devojkari, Vineci, Dardhësi, and Golerani, Toraniku ${ }^{10}$ etc., they exist as toponyms or in the popular memory.

Reasons for abandoning them were conditioned by the social, economic and political factors. In addition to the historical value, these settlements show us the popular form of construction in the time especially before the Turkish invasion. Ruins of Stojan and Dardhës not covered by deposits to the East of the city Permet and to the right of the Vjosa River indicate a large number of houses, which were built in stone using mortar, are clear evidence of an early form of constructing. These rural areas of our country are of special importance concerning the architectural features of the period under study.

One of the main features is their position close to the trade arteries, set deep in the plateau of mountain ridges, a position that clearly reveals their dual character, respectively the agricultural and rural character. Stone buildings, shows clearly that we are talking about a population of a permanent nature preferring to build in durable elements.

These compositional concepts and different architectural elements of construction enjoyed a wide spread popularity among the population in that territory at that time serving as a link between that period and earlier periods, bearing witness to the ethnicity and cultural continuity of our people. The rural dwelling of this period is a simple construction, small and made of stone. So most of the villages of Gjirokastra region, Permet, Kurvelesh etc. are founded as permanent settlements with permanent borders, many centuries before the Turkish invasion. Most of the villages are mentioned for the first time in Turkish documents in 1432.

Traces of this lost history can be found in the diaspora, that were forced to leave these settlements to migrate to southern areas so as to to escape the Turkish yoke.

"Rural Housing and great family11" is a complete work, for whose publication co-operated many architects, historians, archeologists, and geographers and in which are treated issues like: when did the dwellings first started to be build, , the way they were protected, fortification elements and the socio-economic reality of the time. The hilly villages had a relatively balanced development, whereas in the mountainous villages more emphasis was placed on animal husbandry in lowland villages emphasis was placed on agriculture.

According to the type of terrain villages fall into three categories:

\footnotetext{
9 Sheme. Selman. Chameria. The place, population and the economic life. Page 114-117. "PROGRES". Tiranë 2005.

${ }_{10}$ Adhami. Stilian. Overview of the popular culture of the area of Permet. Faqe 22-126. GERVIS. Tiranë 2001.

${ }_{11}$ Muka. Ali. The rural dwelling and the big family. Page 42-75. 344-351. A publication of the Academy of Sciences of Albania. Tiranë 2001.
} 
a. lowland villages are densely populated, located mainly on the West, like those found in Delvina valley, Korca, Pogradec and Kolonja with $48 \%$ of rural settlements.

b. hilly villages have a smaller population, located mainly on the Eastern suburbs along the valleys of the rivers Black Drin , Mat, Shkumbin, Seman, Vjosa and Drino with 51\% of rural settlements.

c. mountain villages occupied $7.7 \%$ of rural settlements and lay on the rough terrain in the Albanian Alps, in the peripheral region of the Black Drin, Eastern lowland and valleys in the Southern Highlands Province.

According to the economic activity there are:

a. settlements of agricultural economy

b. settlements of mixed-type economy

According to the form of property there:

a. co-operative settlements

b. residential agricultural enterprises

According to the administrative function there are:

a. United settlements, an administrative unit with a number of localities functioning also as an economic entity

b. specific settlements representing a settlement

According to the method of construction ${ }^{12}$ and the density of residential buildings there are:

a. compact settlements with residential concentrations on the slopes and at the foot of the hills

b. less compact settlements, the periphery of which consists of stray dwellings

c. new socialist type settlements, located in distinct areas and known for their compactness of layout and construction.

Periods of changing socio-economic systems, the process of moving from the centralized economy to the free market economy can hardly offer other solutions to the mechanical movement of the population, except being spontaneous. This kind of movement carried with it a number of negative consequences in rural areas $^{13}$. The dissertation titled "The dynamics of the Rural Area System in Gjirokastër District14 " in Human Geography presented on 19. 11. 2001 , to obtain the Master's degree analyzes in Chapter II the issue : "Populating the ecosystem in rural area." In this chapter are also analyzed rural areas hierarchy and their typology and policies regulating the rural settlements.

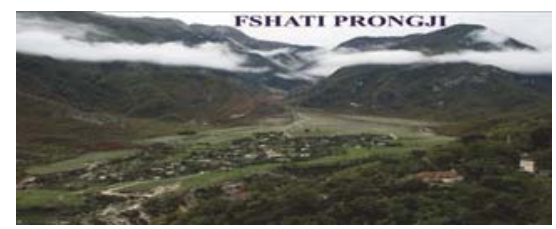

Fig. 4. Prongji village (Gjirokastra district)

This study offers us information of the type :

- Over $98 \%$ of the total number of rural settlements.

- During the historical evolution rural settlements have developed their particular physiognomy and originality. This prcess has affected the social structure, and can be seen as an expression of the organization of agriculture and cultural heritage of its inhabitants, these are reflected on these farming techniques, customs, folklore, traditions, materials, architectural style.

Rural areas are characterized by a landscape architecture with 2-3 storey residential house. These types of settlements have historically affected people's social life, the relationship between them and the outside world.

There are two extreme classical forms, the spread and concentrated, and among them there are other forms which are a mixture of the two types ${ }^{15}$. In Albania, land ownership and social structure have not had a smooth history,due to the

\footnotetext{
12 Bërxholi, A., The changes in the geography of the population in the area Vjosë- Ionian sea (demographic study), Page 57-66. Tiranë 1987.

${ }^{13}$ Hana Lulzim. Telo llia. Transition in Albania: Achievements and challenges. Page 185. MËSONJËTORJA. Tiranë 2005.

14 Sinani.A. The dynamics of the Rural Area System in Gjirokastër district. Page 94-102. Scientific supervior Prof. Dr. Arqile Bërxholi. Gjirokastër November 2011.

${ }^{15}$ Mazniku. Luljeta. Rural Sociology . UBT. Page 84-90. Tiranë 2004.
} 
fact that Albania did not go through the historical stages like feudalism and capitalism. Reflecting the different stages in the course of history have been established different practices in different areas. The 50-year-old socialist system in the field of construction introduced new traditions and changed the contents in accordance with the ideological and political goals. The changes that the settlements uderwent during this time were both quantitative and qualitative. Quantitative changes consisted in increasing the number of buildings in rural areas thereby creating big rural centers tantamount to the city. Qualitative changes, consisted in an effort to adapt new community functions, according to political criteria and in accordance with the typology of the village. For this process, the necessary economic factor was government ownership of the land. As regards the socialist organization of state agricultural co-operatives, rural residential areas are generally characterized by agrarian and mixed settlements, but some villagers made a living working in industrial sectors (mining or wood processing that had been close to their homes). The basic principle of a regulatory plan regarding a settlement was building housing units in different socio-cultural centers.

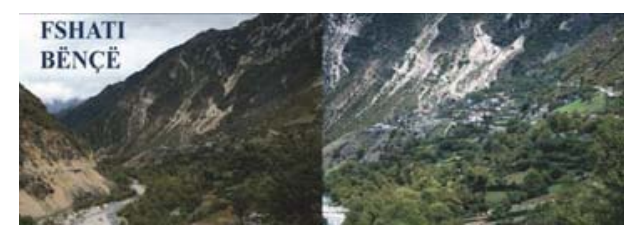

Fig. 5. The village of Bençë (Tepelena District)

\section{Conclusion}

Traditional elements were preserved more in hilly and mountainous areas, but this thing did not occur in lowland areas. Settlement setting expresses the relationship between social groups and material life conditions (natural environment and land). The types of settlements have historically influenced social life of the locals, the relationship between them and the outside world. The spread and distributed type can be found in all geographic areas of the country, as the case may be, or they may even be combined with each other. In the construction of rural settlements have been preserved traditional elements and special features according to the different areas and historic development.

\section{References}

Adhami. S. Overview of the popular culture of the area of Permet. Page 22-126. 236. GERVIS. Tiranë 2001. Adhami. Stilian. Overview of the popular culture of the area of Permet . Page 22-126. GERVIS. Tiranë 2001.

Axhemi. S. Geography of the population and of the settlements. Page 190-211. ALSA. Tiranë 2007.

Bërxholi, A., The changes in the geography of the population in the Vjosë- Ionian sea area ( demographic study), Faqe 9-15; 57-66. Tiranë 1987.

Hana, L., Telo, I. Transition in Albania : Achievements and challenges. Page 185. MËSONJËTORJA. Tiranë 2005.

The Illyrians and Illyria by the ancient authors. Tiranë 1965. Faqe 133.

Lole. Dh. Përmet and its areas until 1912. LUARASI. Page 14-96. Tiranë 2000.

Mazniku, L. Rural sociology. UBT. Page 84-90. Tiranë 2004.

Misja, V., Vejsiu Y., Bërxholi A., The population of Albania ( Demographic study ), Page 150-163. Tiranë 1987.

Muka, A. The walls of the rural dwelling, Albanian Ethnography, Nr.17, 1990.

Muka. Ali. The rural dwelling and the big family. Page 42-75. 344-351. Publication of the Academy of Sciences. Tiranë 2001.

Selenica. T. Albania in 1927. Page . 89. TIRANA. Tiranë 1928.

Sheme. S. Chameria. The place, population and the economic life. Page 114-117. "PROGRES". Tiranë 2005.

Shkurti. S. Albanian Ethnography Nr. 17. The rural dwellings and the agricultural economy in medieval Albania. Page 4-35. Tiranë 1997. Straboni. Geography. Moscow 1964. Page 295.

Thëngjilli, P., The History of the Albanian people (395-1875), Toena publishing house, Tiranë 2004, page.268.

Tirta, M. Movements of the population and the development of the cities (1945-1985), Albanian Ethnography Nr.15, Tiranë 1986.

Tirta, M., Overview of the population who came in dwellings built after the Liberation in agricultural environments, Albanian Ethnography Nr. 13, page .1, Tiranë 1983.

Tirta. M. Albanian Ethnography 18. Migrations of the Albanians. Page 32-71. 169-171. Science . Tiranë 1999. 